\title{
Halal advertising on YouTube: a case study of fast food brands in Malaysia
}

\author{
*Yarar, A.E. \\ Necmettin Erbakan University, Faculty of Social and Humanity Science, Program of Public Relations and \\ Advertising, 42090 Meram/Konya, Turkey
}

\author{
Article history: \\ Received: 6 September 2019 \\ Received in revised form: 18 \\ October 2019 \\ Accepted: 24 December \\ 2019 \\ Available Online: 10 \\ February 2020
}

\section{Keywords:}

Halal concept,

Halal advertising,

Islamic advertising,

Fast-food brands

\section{DOI:}

https://doi.org/10.26656/fr.2017.4(S1).S34

\begin{abstract}
The Halal concept is one of the most important concepts in terms of Muslim societies. They guide their lives according to this line. They determine the standards of their lives and daily life activities according to it. This situation also plays a significant role in the consumption of goods and services and the process of purchasing. Emerging technology and the changing world have provided many Halal products and services. Growing Muslim populations have manufacturers to produce this type of product development. Increasing consumer satisfaction levels over time and rapidly changing preferences, product variety and development, fashion and similar factors have enabled Halal products and services to exist in different forms in the market. It represents not only a brand element or religious phenomenon but also is a symbol of life and culture. Like every symbol used in everyday life, Halal, and Islamic symbols can turn into an object that becomes desire commodity and can lose its meaning. This paper addressed and analyzed the advertising content in terms of Halal advertising and Islamic Advertising through YouTube ads. Besides that, the frequencies of major fast-food brand's (KFC, Burger King, McDonald's, Subway) were identified. Methodologically, the paper utilized both qualitative and quantitative approaches. The literature reviews the contents of the advertising text were analyzed. Also, the signs used in advertising were investigated in this study. The findings showed that the advertising content appeared to be consistent with each other. Also, the Halal emphasis in advertising differs according to brands.
\end{abstract}

\section{Introduction}

Halal is an Arabic word and is referred to as permissible in the Holy Qur'an. A basic acceptance and understanding of what is Halal is central to every Muslim's belief - falling under the umbrella of what is considered to be information that is known by necessity (Wilson, 2014). Consumption is made according to the concepts of Halal and Haram (Özdemir and Yayl, 2014). Halal is not only a brand element but also it is part of a belief system and a moral code of conduct (Wilson and Liu, 2010:108). It is in the realm of business and trade, and it is becoming a global symbol for quality assurance and lifestyle choice (Jumaaton, 2005). As a result, it should not be considered just a religious phenomenon (Torlak, 2010). The question about the concept of Halal begins here.

Although Islamic finance or Halal programs are to be developed with advancing technology, Halal certification or branding processes, it also becomes a commodity in many different areas such as tourism or entertainment. Furthermore, it can be reversed with the basic structure on which it is based, and Halal status can gain new dimensions that are not true. This perspective can be categorized into two main topics.

Firstly, technically according to Shariah, everything is permissible unless stated otherwise. However, Halal logos and Islamic labels are constructs that were created to label a minority of product and service offerings (Wilson, 2014). In recent days, many standards related to Halal certification and Halal industry have been developed. There are many institutions and organizations that hold these standards. JAKIM in Malaysia, HPA in Indonesia, CICOT in Thailand and GIMDES in Turkey, can be given as examples. Also, advertising content and application codes are available for some countries (Malaysian Communications and Multimedia Content Code in Malaysia (CMCF), Advertising Board in Turkey). These institutions, as well as Islamic sensitivity, can be given importance to universal social values. However, with the technical dimension of the subject, the perceptual dimension that may occur with consumers 
should also be highlighted. This structure needs to be established. If these structures are not inspected and controlled, they may lose their meaning over time and may not fulfill their essential duties. Baudrillard (2010) summarizes this situation as follows; indicators of social importance, according to a gathering order, become indicators of social recognition and they become indifferent and lose their meaning.

Additionally, consumption culture and the behavior with culture and religion are closely related to the characteristics of consumers. Differences between people's devotion to religious values lead the lives of individuals, play an important role in shaping their social behaviors. It affects the preferences of individuals such as who they are in contact with and what they consume (Torlak, 2010). Past research affirms that the degree of religiosity is a better predictor than religion when it comes to investigating an individual's consumption behavior (De Run et al., 2010). Brand preference and purchase behavior may change according to the level of religiousness of the person (Özdemir and Yayl1, 2014). This situation can be dangerous if not observed. Bocock (2014) said that the social pressure and group psychology we live in can rapidly undergo change under postmodern conditions, such as pleasure, style, interests, leisure time, political or religious sense of belonging. Consumers who care about their religious values don't express consumption as differentiated by a series of autonomous economic factors. They regard it as a set of social and cultural practices that serve to create differences between social groups (Bocock, 2014).

These criticisms of alienation from Islamic concepts can be summarized in the words of Professor Al-Attas (Al-Attas, 2014): many major key terms in the Islamic basic vocabulary of the languages of Muslim peoples have now been displaced and made to serve absurdly in alien fields of meaning in a kind of regression towards non-Islamic worldviews; a phenomenon which I call the "deislamization" of language. Ignorance and confusion, making possible the infusion of alien concepts, have also let loose the forces of narrow national sentiment and ideologization of ethnic and cultural traditions.

Advertising is one of the tools that play a role in transferring meaning from consumer to cultural products (Odabaş1, 2017). They are capable of re-understanding and redirecting unique codes generated by communities. This case is a very effective method for the advertiser to tell a lot of things by using restricted codes. Although ads are seen as competing with each other, they are supporting each other towards consumption. They have a unique language. This language is used on its own to make that general suggestion that never changes. Their messages are also simple. It is recommended that we buy another object and change ourselves or our lives. With this new product, promises are made that the individual will be better, beautiful, and strong. Individuals who buy the products recommended by the advertisement try to be happy with this fact (Berger, 1995).

Advertising plays an essential role in the Islamic world and Muslim societies as well. Conducting advertising is permissible as long as it never crosses the Shariah law (Al-Makaty et al., 1996). Advertisers produce religious content to reach Muslim target groups. The size of this market attracts the attention of not only Muslim producers but also non-Muslim producers. Advertisements include religious symbols and values. In the field of consumer behavior, the factor of religion, which is among the social and cultural influences affecting the behavior. It has always played an essential role in the purchase behavior of consumers. Religious terminology is used in advertisements to reassure consumers of the Islamic integrity of products and services (Haque et al., 2010). As shown in Table 1, many scholars made definitions on this topic. Of course, the issue should not be limited to the prohibition of nonHalal products and services. When it comes to advertising, the position of advertising on societies, masses, and worldview should also be considered.

To find the answers to these issues, two objectives were identified: i) to analyze the advertising content in terms of Halal advertising and Islamic advertising through YouTube ads; and ii) to investigate the frequencies of major fast-food brand's (KFC, Burger King, McDonald's, Subway) YouTube ads. in terms of Semiotics.

\section{Materials and methods}

\subsection{Advertising in YouTube}

In our age, the most popular media of advertising are social sharing networks. Facebook; strong in terms of advertising, Twitter; news, information, media-oriented, lean but high yield, YouTube; active in visual and advertising access to a wide audience, Google + increases the impact of the Google AdWorks program. Thus, each one stands out with different features (Funk, 2012). YouTube is technically a platform where users can upload, share, and watch video content. Also, it can be said that the purpose of the use of YouTube varies. On YouTube, users can make their publications, create communication channels among themselves, and share their content with the world (Alper, 2012).

Although YouTube is a social network, the possibilities offered by the company are not limited to these. YouTube is also an advertising medium. 
Table 1. Halal Advertising Literature, Azmin Azliza Aziz (2019).

\begin{tabular}{|c|c|c|}
\hline & Viewpoint & Headings \\
\hline Anwar and Saeed (1996) & $\begin{array}{l}\text { They had highlighted the } \\
\text { elements of Islamic } \\
\text { Advertising. }\end{array}$ & $\begin{array}{l}\text { 1. Truthfulness, } \\
\text { 2. Spending Behavior, } \\
\text { 3. Halal and Haram Criteria, } \\
\text { 4. Publication Ethics } \\
\text { 5. Human Dignity. }\end{array}$ \\
\hline Anwar and Saeed (1996) & $\begin{array}{l}\text { They also outlined four } \\
\text { dimensions of Halal } \\
\text { advertising tools that can } \\
\text { be specifically tailored to } \\
\text { achieve. }\end{array}$ & $\begin{array}{l}\text { 1. Healthy competition in the market, } \\
\text { 2. Freedom for consumers to select products which suit functional } \\
\text { and social needs, } \\
\text { 3. İmprovement in the quality of products, } \\
\text { 4. Enhancement of Islamic moral conduct }\end{array}$ \\
\hline Islam and Alam (2013) & $\begin{array}{l}\text { Outlined five dimensions } \\
\text { of advertising in Islamic } \\
\text { perspective. }\end{array}$ & $\begin{array}{l}\text { 1. Precise statement } \\
\text { 2. Prohibited elements as a promotional tool, } \\
\text { 3. Persuasive, } \\
\text { 4. Transparent, } \\
\text { 5. Avoid nudity }\end{array}$ \\
\hline Abdul Cader (2015) & $\begin{array}{l}\text { Quranic Message that } \\
\text { influence Halal } \\
\text { Advertising. }\end{array}$ & $\begin{array}{l}\text { 1. Haram (impermissible), alcohol, gambling, deceptive advertising } \\
\text { depiction of idols, the non-Islamic portrayal of woman, } \\
\text { 2. Islamic activities, respecting Islamic duties such as prayer times, } \\
\text { 3. Being thankful for the blessing of Allah. }\end{array}$ \\
\hline Shafiq et al. (2017) & $\begin{array}{l}\text { They defined four general } \\
\text { rules of Islamic } \\
\text { advertising. }\end{array}$ & $\begin{array}{l}\text { 1. It should not exploit the basic instincts of consumers and should } \\
\text { avoid provoking desires that can never be fulfilled, } \\
\text { 2. It should be based on truth and complete revealing of all product } \\
\text { attributes, } \\
\text { 3. The product should not be haram neither should be it harmful, } \\
\text { 4. It should advocate consumption as a form of worship and } \\
\text { promote moderation in the same. }\end{array}$ \\
\hline $\begin{array}{l}\text { Purnama and Safira } \\
\text { (2017) }\end{array}$ & $\begin{array}{l}\text { Provide Islamic ethical } \\
\text { guidelines for advertising. }\end{array}$ & $\begin{array}{l}\text { 1. Does not show inappropriately dressed people, } \\
\text { 2. Does not use sexual appeal, } \\
\text { 3. Does not use emotional appeal, } \\
\text { 4. Does not use fear appeal, } \\
\text { 5. Does not use portray immorality, } \\
\text { 6. Does not use profane language, } \\
\text { 7. Does not depict disbelief in Islam, } \\
\text { 8. Does not encourage extravagance, } \\
\text { 9. Does not use false testimonies, } \\
\text { 10. Does not use exaggerate by making claims which are } \\
\text { unsupported by evidence. }\end{array}$ \\
\hline Shafiq et al. (2017) & $\begin{array}{l}\text { Described the } \\
\text { characteristics of Islamic } \\
\text { advertising. }\end{array}$ & $\begin{array}{l}\text { 1. Ethical, } \\
\text { 2. Credible, } \\
\text { 3. Nondeceptive } \\
\text { 4. Simple } \\
\text { 5. Humane. }\end{array}$ \\
\hline
\end{tabular}

Nowadays, companies can carry out advertising activities via YouTube. In this context, it can be said that YouTube is used for various purposes in advertising activities. It can be realized a lot of goals through YouTube, such as creating brand awareness, advertising a specific product, providing product support, and retail sales (Akar, 2011).

The use of social media is also crucial in Malaysia. According to the Kemp (2018), the most followed social media channel in Malaysia is Google with $70 \%$ and YouTube with 69\% reported in Digital 2018: Malaysia. This situation is followed by WhatsApp, Instagram, and Facebook Messenger, respectively. Besides, online advertising comes first with $31 \%$ as an advertising medium. In Malaysia, $79 \%$ of the total population is internet users. $75 \%$ of the population are active social media users. $69 \%$ of the population actively follows social media on their mobile phones (Kemp, 2018).

\subsection{Methodology}

The objectives of this study are twofold. First, it aims to analyze the advertising content in terms of Halal advertising and Islamic Advertising through YouTube ads. Second, it intends to investigate the frequencies of major fast-food brand's (KFC, Burger King, McDonald's, Subway) and YouTube ads in the context of Semiotics. In the literature part of this research, Halal Concept and uses, Halal Advertising and Islamic Advertising are examined. Based on these issues, Halal/ Islamic advertising elements and dimension are grouped 
under six main headings. These headings were formed by adhering to Anwar and Saeed (1996) and Aziz et al. (2019). Some drivers are matched because of the similarity of meaning. For instance, truthfulness can be categorized under credibility; spending behavior can be categorized under non-deceptive. In summary, we identified six elements or characteristics, namely, credibility, non-deceptive, simplicity, dignity, humane, and publication ethics. Twenty-three coding items were determined considering these factors. These items have been developed with inspiration from previous work.

The second stage of the study is the analysis of advertising in terms of semiotics. To investigate what the meaning of advertisement is, semiotics is one of the main methods used. For a better understanding of semiotics, firstly, it is useful to understand what the signs are. The signs describe the element resulting from the combination of the signifier and what is signified (Barthes, 1979). According to semiotics, all signs in our world of life have meaning. Everything that has meaning in an image is a sign. Therefore, it is a semiotic research object. Semiotics encompasses many branches of anthropology and sociology. Any human activity, such as music, architecture, etiquette, advertising, fashion, literature, can each be approached in terms of semiotics (Culler, 1985). In handling the misreading of the photograph advertisements, Barthes (1979) divided the signs into two categories. They are verbal parts and nonverbal signs. In this research, a dual distinction has been established in the form of verbal and nonverbal signs. Quotation, Slogan, Capital Letter, Title of Product and notice as a verbal; color, the picture of human, illustration and logo as a non- verbal (Sofiyah, 2019). In addition to this scale, human voice and music are also added. Also, it is determined how the Halal logo is included in the advertisement.

This research was conducted in July 2019. The publication dates of the ads reviewed have not been considered. It has examined a total of 69 advertisements. Based on the literature, a total of 23 coding items were identified. The advertising content from the official Malaysia YouTube page was collected and analyzed by two coders (authors) independently.

\section{Results and discussion}

This analysis is based on 69 advertisements which contained in major fast-food brands' YouTube Channels.

As shown in Table 2, the total rates of likes of ads are 45,092, the overall percentages of dislike are 19,603, the total rates of comments are 45 , and the total rates of views are $60,433,240$.
Table 2. Advertising rates

\begin{tabular}{cccc}
\hline Like & Dislike & Comment & Views \\
\hline 45.092 & 19.603 & 45 & 60.433 .240 \\
\hline
\end{tabular}

As shown in the Table 3, there are 235 verbal and 138 nonverbal signs in the advertisements. Also, $76.81 \%$ of ads include the human voice. $79.71 \%$ of the ads have music. $40.57 \%$ of ads included product prices, $78.26 \%$ of ads have a slogan, texts are capitalized in $92.75 \%$ of ads, $42.02 \%$ of advertisements took notices, $50.07 \%$ of the ads included pictures of human, while $50.07 \%$ of the ads have illustrations, brand logos are included in $98.5 \%$ of the ads., $76.81 \%$ of ads included human voices, $79.71 \%$ of ads used music.

Table 3. Verbal and non-verbal rates

\begin{tabular}{clcc}
\hline Type of signs & Categories of signs & Score & $\%$ \\
\hline \multirow{5}{*}{ Verbal } & Quotation & 28 & $40.57 \%$ \\
& Slogan & 54 & $78.26 \%$ \\
& Capital Letter & 64 & $92.75 \%$ \\
& Title of Product & 60 & $86.95 \%$ \\
& Notice & 29 & $42.02 \%$ \\
\hline Total & & 235 & \\
\hline \multirow{5}{*}{ Non-Verbal } & Color & & \\
& The picture of human & 35 & $50.70 \%$ \\
& Illustration & 35 & $50.70 \%$ \\
& Logo & 68 & $98.50 \%$ \\
\hline Total & & 138 & \\
\hline \multicolumn{5}{c}{} & 53 & $76.81 \%$ \\
\hline & Human Voice & 55 & $79.71 \%$ \\
\hline
\end{tabular}

Halal emphasis on ads (Table 4), the use of Halal logos, and the duration of the logos were measured. According to these results, $71.01 \%$ of the ads included Halal certificates. Also, in $51.02 \%$ of the ads, the Halal certificate was seen in the entire advertisement. Halal certificates were seen at the end of the advertisement in $48.97 \%$ of the advertisements.

Table 4. Halal emphasis

\begin{tabular}{|c|c|c|c|}
\hline \multicolumn{4}{|c|}{ Halal emphasis \% } \\
\hline \multirow{4}{*}{ Halal Signs } & \multirow{2}{*}{$\begin{array}{c}\text { Certificate } \\
\text { (Logo) }\end{array}$} & exist & not \\
\hline & & $70.01 \%$ & $29.99 \%$ \\
\hline & \multirow{2}{*}{$\begin{array}{c}\text { Duration of } \\
\operatorname{logo}\end{array}$} & All & in the end \\
\hline & & $51.02 \%$ & $48.97 \%$ \\
\hline
\end{tabular}

Table 5 tabulates the semiotics signs of Brands, according to this;

- It is seen that, KFC came first in the rates of views with $49.07 \%$.

- All of the comments only belonged to Burger King ads. Other brands comments closed.

- The use of color in all ads quite varied. In addition to their own logo colors, brands used mostly red, black and white colors.

- In the use of the Halal Logo, KFC ranked first with 
Table 5. Brand's results

\begin{tabular}{|c|c|c|c|c|c|c|c|c|c|c|}
\hline & & Mc Donald's & $\%$ & Burger king & $\%$ & KFC & $\%$ & Subway & $\%$ & Total \\
\hline Video & Number of videos & 20 & $28.98 \%$ & 14 & $20.28 \%$ & 20 & $28.98 \%$ & 15 & $21.73 \%$ & 69 \\
\hline \multirow{4}{*}{ General } & Views & 21952544 & $36.32 \%$ & 3829147 & $6.33 \%$ & 29659003 & $49.07 \%$ & 4992546 & $8.26 \%$ & 60433240 \\
\hline & Like & 17016 & $37.73 \%$ & 416 & $0.92 \%$ & 23601 & $52.33 \%$ & 4059 & $9.00 \%$ & 45092 \\
\hline & Dislike & 6724 & $34.30 \%$ & 127 & $0.64 \%$ & 12336 & $62.92 \%$ & 416 & $2.12 \%$ & 19603 \\
\hline & Comment & 0 & $0.00 \%$ & 45 & $100.00 \%$ & 0 & $0.00 \%$ & 0 & $0.00 \%$ & 45 \\
\hline \multirow{5}{*}{ Verbal } & Quotation & 3 & $10.71 \%$ & 5 & $17.85 \%$ & 11 & $39.28 \%$ & 9 & $32.14 \%$ & 28 \\
\hline & Slogan & 19 & $65.18 \%$ & 8 & $15.68 \%$ & 18 & $33.33 \%$ & 9 & $16.66 \%$ & 54 \\
\hline & Capital letter & 17 & $26.56 \%$ & 14 & $21.87 \%$ & 20 & $31.25 \%$ & 13 & $20.31 \%$ & 64 \\
\hline & Title of product & 17 & $28.33 \%$ & 13 & $21.66 \%$ & 17 & $28.33 \%$ & 13 & $21.66 \%$ & 60 \\
\hline & Notice & 9 & $31.03 \%$ & 5 & $17.24 \%$ & 8 & $27.58 \%$ & 7 & $24.13 \%$ & 29 \\
\hline \multirow{4}{*}{$\begin{array}{l}\text { Non } \\
\text { verbal }\end{array}$} & Color & & & & & & & & & \\
\hline & The picture & 14 & $40.00 \%$ & 9 & $25.71 \%$ & 13 & $37.14 \%$ & 5 & $14.28 \%$ & 35 \\
\hline & Illustration & 8 & $22.85 \%$ & 3 & $8.57 \%$ & 10 & $28.57 \%$ & 14 & $40.00 \%$ & 35 \\
\hline & Logo & 20 & $29.41 \%$ & 13 & $19.11 \%$ & 20 & $29.41 \%$ & 15 & $22.05 \%$, & 68 \\
\hline \multirow{2}{*}{ Sound } & Human voice & 20 & $37.73 \%$ & 9 & $16.98 \%$ & 14 & $26.41 \%$ & 10 & $18.86 \%$ & 53 \\
\hline & Music & 18 & $32.72 \%$ & 7 & $12.72 \%$ & 16 & $29.09 \%$ & 14 & $25.45 \%$ & 55 \\
\hline \multirow{3}{*}{ Halal } & Logo & 18 & $36.73 \%$ & 12 & $24.48 \%$ & 19 & $38.77 \%$ & 0 & $0.00 \%$ & 49 \\
\hline & $\begin{array}{l}\text { Duration of logo } \\
\text { (all) }\end{array}$ & 14 & $56.00 \%$ & 2 & $8.00 \%$ & 9 & $36.00 \%$ & 0 & $0.00 \%$ & 25 \\
\hline & Duration of logo & 4 & $16.66 \%$ & 10 & $41.66 \%$ & 10 & $41.66 \%$ & 0 & $0.00 \%$ & 24 \\
\hline
\end{tabular}

38.77\%, McDonalds ranked second with 36.73\% and Burger King ranked third with $24.48 \%$. The Halal Logo was never used in Subway ads.

- McDonalds is the company that gave the most place to the Halal Logo in ads. In $14 \mathrm{McDonalds'}$ ads, the Halal Logo was shown in whole videos. In the other 4 ads, the logo was shown in the end of videos. This rate was 9 to 10 for $\mathrm{KFC}$ and 10 to 2 for Burger King.

\subsection{Burger King}

Burger King ads usually based on product promotions. These ads include cultural and religious elements such as Chinese Christmas. It is also seen that these advertisements have an intercultural emphasis. For example; an ad shows that the Muslim family who are guests of the Chinese family's home. Some other ads include Fast food versions of Malaysian cultural products such as Nasi Lemak. On the other hand, the presentation of new products constitutes the content of the ads. Characters have a crown on their heads so this gives the impression that customers who consume products are kings. Ads contain references to the originality of the content used in the product such as " $100 \%$ Beef!". To summarize; it is seen that these ads have product information and experience advice (try today, Taste is king etc.). Exaggeration is seen in ads. Ads include "Consume more!" emphasis. There are gifts and discount offer.

\section{$3.2 \mathrm{KFC}$}

In particular, advertisements include entertainment. For example, it becomes clear that parents who consume products become children and have fun as children. A special song was composed and published for Ramadan (Raya Selamba). In general, ads are published in three different languages (Malay, English, Chinese). In addition, "Salam Ramadan" ad has religious, family and cultural emphasis. Advertisements include animal use. The desired language was used to describe the characteristics of the product. In general, this has turned into a story with an element of attractiveness (Horror scene-ghost). There is an advertisement about Chinese New Year. If we make an overall assessment, the product information is frequently included. Experience is recommended. (get it today...). It is particularly emphasized that the elderly and parents become childish and happy during and after consuming KFC. There are many exaggerations in advertising. To avoid cheating, there are warnings such as limited time only. A persistent discourse was used for product experience. There are also warnings like "last call".

\subsection{McDonald's}

There is a cultural emphasis on developing a product called "Nasi MCD". In addition, the characters eat this dish with their hands. There are several different ads specific to Ramadan. These ads include Islamic emphasis (prayer, iftar with family or friends etc.). In addition, it is emphasized that a courier, who is fasting, works with 
patients in the hot weather. Some ideas are given in the message such as when you eat alone, you only hear the sound of the food or you will be happy when you eat with family and friends. Cinematic fiction is widely used. Exaggerated and absurd issues such as separation, pain of love, deception, secret, are also used. The hamburgers are likened to candidates competing in the election, which they give promises. Ads for extra spicy products can be distinguished from others. Because in these commercials people suffer because of the extra spice. Thus, the exaggeration that the ad tries to convey in the connotation has emerged with real experiences. As a result, product information is given a lot. Experience has recommendations. It has the most exaggerated ads among the 4 brands. In ads, there is an emphasis on eating even if it is not needed. In addition, it is recommended to eat meat by saying that you should not eat chicken anymore. In advertising, there is a lot of insistence. There are many gifts and promotional notice in ads.

\subsection{Subway}

The language used in advertising is generally Malay. Ads of this brand are general notices. The rate of fictional films is $25 \%$. Among these four brands, there is only a reference to another brand, institution or company (Star Wars). In other words, the use of a famous brand is available. In general, product information is given in detail. It is recommended for experience. There are a lot of exaggerated messages, and also many gifts and promotional notices in ads.

\section{Conclusion}

According to the results, the YouTube ads of these four major brands appear in different positions in terms of the usage of the Halal concept and Halal advertising. McDonald's comes first in terms of the use of Halal logos and Islamic values and symbols. The Subway brand does not include Islamic symbols, including the use of Halal logo. In most advertisements, clearly specifying the content of products may be attributed to the rules of Halal advertising and Islamic advertising. It seems that the advertisements do not include controversial issues and issues that require sensitivity. It can be said that all brands pay attention to this issue. In addition, there is almost no content on issues such as the female body and its commodification, and nudity and discrimination. However, in addition to all these positive aspects, due to the nature of advertising, the emphasis on exaggeration and necessity is unfortunately in all brands. Persuasion, incentives, gift offerings can be said to be found in all advertisements. To sum up, the ads that have the consequences of creating a culture and creating the agenda also include elements such as the concept of Halal, Halal advertising and Islamic advertising characteristics. However, as it was conveyed in the literature, one should hope that the concept of Halal should not lose its meaning and value.

\section{Acknowledgement}

This research is supported by TUBITAK BIDEB.

\section{References}

Abdul Cader, A. (2015). Islamic challenges to advertising: a Saudi Arabian perspective. Journal of Islamic Marketing, 6(2), 166-187. https:// doi.org/10.1108/JIMA-03-2014-0028

Akar, E. (2011). Sosyal Medya Pazarlamas1., p. 106-107. Ankara: Elif Yayınevi.

Al-Attas, S.M.N. (2014). Prolegomena to the Metaphysics of Islam. Malaysia: Penerbit UTM Press.

Al-Makaty, S.S., Van Tubergen, G.N., Whitlow, S.S. and Boyd, D.A. (1996). Attitudes toward advertising in Islam. Journal of Advertising Research, 36(3), 1627.

Alper, A. (2012). Sosyal Ağlar., p. 115 Ankara: Pelikan Yayıncilik.

Anwar, M. and Saeed, M. (1996). Promotional tool of marketing: an Islamic perspective. Intellectual Discourse, 4, 15-30.

Aziz, A.A., Rahin, N.M. and Asri, N.M. (2019). Halal Advertising on Facebook: A Case Study of Health and Beauty Products in Malaysia. In Management of Shari'ah Compliant Businesses., p. 177-192. USA: Springer, Cham. https://doi.org/10.1007/978-3-03010907-3_16

Barthes, R. (1979). Gösterge Bilim İlkeleri. Ankara: Kültür Bakanlığı Yayınları.

Baudrillard, J. (2010), Tüketim Toplumu, (Çev. Hazal Deliceçaylı ve Ferda Keskin), İstanbul: Ayrıntı Yayınları.

Berger, J. (1995). Görme Biçimleri. (Çev: Yurdanur Salman). (6. Bask1). İstanbul: Metis Yayınları. [In Turkish].

Bocock, R., (2014), Tüketim. Ankara: Dost kitabevi.

Culler, J. (1985). Suassure. (Çev: Nihal Akbulut). İstanbul: AFA Yayıncıl1k.

Kemp, S. (2018). Digital 2018: Malaysia. Retrieved on July 20, 2019 from Datareportal website: https:// datareportal.com/reports/digital-2018-malaysia

De Run C.E., Mohsin Butt, M., Fam, K.S. and Yin Jong, H. (2010). Attitudes Towards Offensive Advertising: 
Malaysian Muslims' Views. Journal of Islamic Marketing, 1(1), 25-36. https:// doi.org/10.1108/17590831011026204

Funk, T. (2012). Advanced Social Media Marketing. How to Lead, Launch and Manage a Succesful Social Media Program. USA: Apress. https:// doi.org/10.1007/978-1-4302-4408-0

Haque, A., Ahmed, K. and Irfath Jahan, S. (2010). Shariah Observation: Advertising Practices of Bank Muamalat İn Malaysia. Journal of Islamic Marketing, 1(1), 70-77. https:// doi.org/10.1108/17590831011026240

Islam, M.E. and Alam, M.Z. (2013). Advertising: An Islamic Perspective. International Journal of Ethics in Social Sciences, 1(1), 105-116.

Jumaaton, A. (2005). Malaysian 'Halal Journal' Hits UK, UAE markets. Retrieved on July 20, 2019 from Islam Online website: https:// archive.islamonline.net/English/News/2005-02/21/ article04.shtml/

Odabaşı, Y. (2017). Tüketim Kültürü, Yetinen Toplumdan Tüketen Topluma. Istanbul: Aura yayınları. [In Turkish].

Özdemir, H. and Yayl1, A. (2014). Tüketicilerin Helal Sertifikalı Ürün Tercihleri Üzerine Bir Araştırma İstanbul İli Örneği. İşletme Araştırmaları Dergisi, 6, 183-202. [In Turkish].

Purnama, F.A. and Safira, A. (2017). Investigating Islamic advertising ethics: Perceptions of Indonesian Muslims. Journal of Emerging Economies and Islamic Research, 5(2), 43-57.

Shafiq, A., Haque, A., Abdullah, K. and Jan, M.T. (2017). Beliefs about Islamic advertising: an exploratory study in Malaysia. Journal of Islamic Marketing, 8(3), 409-429. https://doi.org/10.1108/ JIMA-02-2015-0018

Sofiyah, A.N. (2019). Semiotic analysis on Fast Food Restaurant advertisements. Surabaya, Indonesia: State Islamic University of Sunan Ampel, BSc. Thesis.

Torlak, Ö. (2010) İslam Ülkeleri Arasında Helal Ürün Pazarlama Potansiyeli, Problemleri ve Çözüm Önerileri Potansiyeli, Problemleri ve Çözüm Önerileri. Tüketici ve Tüketim Araştırmaları Dergisi, 4(2), 1-10. [In Turkish].

Wilson, J.A. (2014) The halal Phenomenon: An Extension or New Paradigm? Social Business, 4(3), 255-271. doi.org/10.1362/204440814X14103454934294

Wilson, J.A. and Liu, J. (2010). Shaping the Halal into a brand? Journal of Islamic Marketing, 1(2), 107-123. https://doi.org/10.1108/17590831011055851 